\title{
HUBUNGAN PERILAKU CARING PERAWAT DENGAN TINGKAT KEPUASAN PASIEN ASING YANG MENJALANI RAWAT INAP
}

\author{
I Gede Wirajaya*, IGAA Sherlyna Prihandhani², I.G.Ngr. Agung Pradnyana Artha ${ }^{3}$ \\ STIKES Bina Usada Bali ${ }^{1,2,3}$ \\ e-mail:wirajayaigede@gmail.com
}

\begin{abstract}
The feeling of dissatisfaction of foreign patients undergoing treatment in a hospital is influenced by various factors. In addition to hospital cleanliness, nurses caring factor is very important to the level of satisfaction of foreign patients themselves. Nurses caring is a dynamic approach, where nurses work to further enhance their care for patients in order to meet the basic needs of patients, so satisfaction as an indicator of the quality of health services can be achieved. This study aimed at determine the correlation between nurse caring behavior and the level of satisfaction of foreign patients undergoing hospitalization care in the ward of the special hospital for surgery BIMC Siloam Nusa Dua. The study method used was descriptive correlation with cross sectional approach. The sample of the study consisted of 30 people who were determined by the criteria of inclusion and exclusion. Data were collected by questionnaire and analyzed using the Spearman Rho test. The results obtained from 30 respondents caring nurses caring behavior was good and patient satisfaction shown by patients to nurses tend to be satisfied. There was a very significant correlation between nurse caring behavior with the Level of Satisfaction of Foreign Patients undergoing hospitalization as evidenced by the value (P value $<0.001, r=0.967)$. The advice for nurses is consistency in maintaining and increasing concern for patients so that the quality and quality of the hospital will be maintainedut.
\end{abstract}

Keywords: caring, nurses, patient satisfaction

\begin{abstract}
ABSTRAK
Rasa ketidakpuasan pasien asing yang menjalani perawatan di rumah sakit dipengaruhi oleh berbagai faktor. Selain kebersihan rumah sakit, faktor caring perawat merupakan hal yang sangat berperan penting terhadap tingkat kepuasan pasien asing itu sendiri. Caring perawat merupakan suatu cara pendekatan yang dinamis, dimana perawat bekerja untuk lebih meningkatkan kepeduliannya kepada pasien demi memenuhi kebutuhan dasar pasien, sehingga kepuasan sebagai indikator mutu pelayanan kesehatan dapat tercapai. Penelitian ini bertujuan untuk mengetahui adanya Hubungan Perilaku Caring Perawat Dengan Tingkat Kepuasan Pasien Asing Yang Menjalani Rawat Inap di Ruang Rawat Inap Rumah Sakit Khusus Bedah BIMC Siloam Nusa Dua. Metode penelitian yang digunakan adalah deskriptif korelasi dengan pendekatan cross sectional. sampel penelitian berjumlah 30 orang yang ditentukan dengan kriterian inklusi dan ekslusi. data dikumpulkan dengan kuesioner dan dianalisis menggunakan uji Spearman Rho. Hasil penelitian didapatkan dari 30 responden perilaku caring perawat tergolong baik dan kepuasan pasien yang ditunjukkan pasien kepada perawat cenderung puas. Terdapat hubungan yang sangat significant antara Perilaku Caring Perawat dengan Tingkat Kepuasan Pasien Asing Yang Menjalani Rawat Inap yang dibuktikan dengan nilai (Pvalue $<0,001, r=0,967$ ). Saran bagi Perawat adalah konsistensi menjaga dan meningkatkan kepedulian terhadap pasien dengan demikian kualitas dan mutu rumah sakit akan terjaga.
\end{abstract}

Kata kunci: caring, perawat, kepuasan pasien

\section{PENDAHULUAN}

Rumah sakit adalah salah satu sarana pelayanan kesehatan yang sering dimanfaatkan oleh masyarakat luas dalam mencari bantuan pengobatan. Kualitas pelayanan rumah sakit sebagai institusi yang menghasilkan produk teknologi jasa kesehatan khususnya sangat tergantung pada kualitas pelayanan keperawatan yang diberikan kepada masyarakat. Dengan cara pendekatan mutu pelayanan dan kepuasan konsumen menjadi salah satu strategi penting yang tidak bisa diabaikan (Suryani, 2015)

Memahami kebutuhan dan keinginan pasien adalah hal penting yang mempengaruhi kepuasan pasien. Pasien adalah orang sakit yang 
dirawat dokter dan tenaga kesehatan lainnya ditempat praktek. Kepuasan adalah perasaan senang seseorang yang berasal dari perbandingan antara kesenangan terhadap aktivitas dan suatu produk dengan harapannya. Sehingga dapat disimpulkan bahwa kepuasan pasien adalah perasaan atau kesan pasien secara emosional (senang ataupun kecewa) terhadap pelayanan yang diterimanya yang sesuai maupun yang tidak sesuai dengan harapannya dengan cara membandingkan harapan dan realita (Nursalam, 2011).

Ketidakpuasan merupakan salah satu faktor yang sangat berpengaruh terhadap kualitas dan mutu rumah sakit itu sendiri, dimana semakin banyak rasa ketidakpuasan yang dirasakan oleh pasien terhadap pelayanan suatu rumah sakit maka semakin buruk juga citra rumah sakit tersebut di masyarakat (Supardi, 2009). Beberapa penelitian membuktikan mutu pelayanan kesehatan yang tinggi akan memenuhi harapan pemakai jasa kesehatan. Semakin tinggi mutu pelayanan, akan menurunkan angka kejadian yang tidak diharapkan dan akan memberikan kepuasan pada pelanggan (J Kristianto, 2015). Selain menyebabkan negative marketing, ketidakpuasan pasien juga dapat menyebabkan peningkatan complain dan penurunan kepatuhan pasien dalam proses medikasi (Shelton, 2010).

Perawat sebagai salah satu tenaga medis yang berada 24 jam dengan pasien dan sebagai pemberi asuhan keperawatan dalam memenuhi kebutuhan dasar pasien selama dirawat memegang peranan penting dalam peningkatan kepuasan pasien. Pemberian pelayanan keperawatan yang didasari oleh perilaku caring perawat mampu meningkatkan kualitas pelayanan kesehatan. Perilaku caring perawat tidak hanya mampu meningkatkan kepuasan pasien, namun juga dapat menghasilkan keuntungan bagi rumah sakit (Kurnia, 2017).

Caring adalah sentral untuk praktik keperawatan, karena caring merupakan suatu cara pendekatan yang dinamis, dimana perawat bekerja untuk lebih meningkatkan kepeduliannya kepada pasien. Perawat merupakan tenaga kesehatan yang paling sering berinteraksi langsung dengan pasien. Perawat harus dapat melayani pasien dengan sepenuh hati dan memerlukankemampuan untuk memperhatikan orang lain, keterampilan intelektual, teknikal dan interpersonal yang tercermin dalam perilaku caring (Nanda, 2011). Dalam Theory of Human
Caring, mempertegas bahwa caring sebagai jenis hubungan dan interaksi yang diperlukan antara pemberi dan penerima asuhan untuk meningkatkan dan melindungi pasien sebagai manusia, dengan demikian mempengaruhi kesanggupan pasien untuk sembuh (Watson, 2009)

Rumah sakit adalah salah satu perusahaan/institusi yang akan terkena dampak dari diberlakukannya AFTA/MEA karena perusahaan dari luar akan datang. Tantangan bagi rumah sakit adalah tantangan untuk bersaing, baik dengan sesama pemberi pelayanan kesehatan di dalam negeri maupun luar negeri. Kompetisi dalam memberikan serta meningkatkan kepuasan konsumen atau pasien yang bermutu lebih baik sebagai fokus utama pelayanan (Zukhrina, 2015).

Bali adalah salah satu daerah di Indonesia yang terkenal akan pariwisatanya. Berdasarkan data dari Dinas Pariwisata Provinsi Bali Tahun 2013 setiap tahunnya terjadi peningkatan kunjungan wisatawan mancanegara yaitu sebesar 2.892.019 orang. Hal ini tidak menutup kemungkinan bahwa Provinsi Bali dapat menjadi wisata kesehatan (medical tourism). Bali juga ditargetkan pemerintah menjadi pengembangan health tourism karena selain potensi pariwisata yang luar biasa juga disebabkan oleh fasilitas kesehatan yang telah maju. Dampak dari adanya wisatawan yang datang salah satunya mengenai pelayanan kesehatan yang memadai. Para wisatawan tidak hanya berlibur, namun ketika mereka sakit atau ingin melakukan pemeriksaan kesehatan, akan segera mencari pelayanan kesehatan yang berkualitas (Putra, 2014).

Data yang diperoleh dari RS Online (Putra, 2014), diketahui bahwa RS Privat Swasta pada tahun 2013 yaitu sebanyak 20 Rumah sakit dibandingkan dengan Rumah Sakit publik sebanyak 50 Rumah Sakit dari total seluruh Rumah Sakit di Provinsi Bali sebesar 72 Rumah Sakit. Hal ini, menyebabkan persaingan antar Rumah Sakit swasta pada umumnya dalam memberikan layanan kesehatan dan menarik pasien cukup ketat dan kompetitif di Provinsi Bali. Data yang didapatkan terkait jumlah pasien asing yang rawat inap di Rumah Sakit Khusus Bedah BIMC Siloam Nusa Dua sebesar 910 orang pada Tahun 2016 dan mencapai 1107 orang pada Tahun 2017. Peningkatan angka kunjungan pasien asing yang menjalani rawat inap ini menunjukan bahwa semakin tingginya harapan pasien untuk mendapatkan pelayanan yang baik selama 
menjalani perawatan, sehingga Rumah Sakit khususnya perawat harus mampu memenuhi kebutuhan dan harapan pasien. Terdapat lima tipe tuntutan dan harapan pasien kepada perawat sebagai pemberi pelayanan yaitu, responsif (mereka harus bersedia dan siap untuk melayani), kompeten (mereka harus mengetahui tugas mereka), sopan (ramah, tamah, hormat, beretika baik, dan fleksibel), kredibilitas (mereka dapat dipercaya dan jujur), dan sensitif (mereka mengerti akan kebutuhan pasien) memberikan perhatian kepada pasien, dan peka terhadap lingkungan (Kotler, P. \& Keller, 2007)

Berdasarkan hasil wawancara pada studi pendahuluan yang dilakukan di Ruang Rawat Inap Rumah Sakit Khusus Bedah BIMC Siloam Nusa Duapada Tanggal 5 Juli 2019, dari total 10 pasien 7 diantaranya mengungkapkan kepuasannya terkait perilaku caring yang diberikan oleh perawat selama menjalani perawatan di rumah sakit, namun 3 lainnya mengungkapkan kurang puas terhadap perilaku caring yang diberikan oleh perawat seperti kurangnya kepedulian perawat terhadap pasien, kurangnya rasa tanggung jawab perawat terhadap pasien dan respon perawat saat pasien membutuhkan bantuan perawat kurang cepat. Pasien mengatakan terkadang harus menunggu 15 sampai 20 menit untuk menunggu kedatangan perawat ke ruangan. Survey yang pernah dilakukan oleh Rumah Sakit Khusus Bedah BIMC Siloam Nusa Dua pada bulan Maret Tahun 2019 terkait kepuasan pasien dengan pelayanan kesehatan rumah sakit menunjukan bahwa $88 \%$ pasien merasa puas terhadap pelayanan kesehatan yang didapat. Survey yang dilakukan oleh RS Khusus Bedah BIMC Siloam Nusa Dua belum spesifik menilai tentang perilaku caring perawat dengan tingkat kepuasan pasien asing.

Perbedaan latar belakang budaya pasien asing yang menjalani rawat inap mempengaruhi pula tingkat kepuasannya terhadap suatu pelayanan. Kehadiran perawat dianggap sangat penting bagi pasien untuk mendengarkan keluhan mereka, menemani mereka dan membantu mereka dalam memenuhi keperluannya serta menjelaskan tentang informasi terkait tindakan selama menjalani perawatan. Kemajuan teknologi dan tingkat pengetahuan yang berbeda antara pasien barat dan timur ikut mempengaruhi tuntutan akan kebutuhan pasien. Semakin banyak pengetahuan yang dimiliki maka semakin besar pula keinginan pasien untuk mendapatkan informasi lebih tentang kondisi kesehatannya dan pasien akan cenderung lebih kritis menuntut pelayanan keperawatan (Geri-ann, 2015). Berdasarkan uraian diatas, peneliti tertarik melakukan penelitian untuk meneliti dan mengetahui secara spesifik apakah perilaku caring perawat mempengaruhi kepuasan pasien asing yang menjalani rawat inap dan untuk mampu bersaing dalam pasar global dalam peningkatan kualitas pelayanan keperawatan.

\section{METODE}

Desain penelitian ini merupakan jenis penelitian deskriptif korelasi dimana penelitian ini bertujuan untuk menjelaskan hubungan antar variabel bebas yaitu perilaku caring perawat dengan variabel terikat yaitu kepuasan pasien asing. Rancangan penelitian dalam penelitian ini menggunakan rancangan cross sectional. Pada desain penelitian cross sectional, data penelitian dapat dikumpulkan sesuai kondisi saat penelitian tersebut berlangsung, sehingga pengumpulan data cukup dilakukan sekali atau pada waktu penelitian dilakukan tanpa harus melihat latar belakang atau kejadian yang telah lalu maupun akan datang (Siswanto, 2013).

Menurut (Hidayat, 2007), populasi merupakan seluruh objek dengan karakteristik tertentu yang diteliti. Populasi yang digunakan dalam penelitian ini yaitu populasi pasien asing yang dirawat inap di Ruang Rawat Inap Rumah Sakit BIMC Siloam Nusa Dua dalam satu bulan. Jumlah populasi dalam penelitian ini adalah berjumlah 92 orang.

Sampel penelitian adalah bagian populasi yang akan diteliti atau sebagian jumlah dari karakteristik yang dimiliki oleh populasi (Hidayat, 2007). Sampel yang digunakan dalam penelitian ini adalah jumlah pasien asing yang menjalani rawat inap di Rumah Sakit Khusus Bedah BIMC Siloam Nusa Dua dengan memperhatikan kriteria inklusi dan eksklusi. Jumlah sampel pada penelitian ini sebanyak 30 orang.

\section{HASIL}

Karakteristik Responden Penelitian di RSK Bedah BIMC Siloam Nusa Dua 
Tabel 1.

\section{Karakteristik Responden Berdasarkan} Pendidikaan

\begin{tabular}{ccc}
\hline $\begin{array}{c}\text { Kategor } \\
\mathrm{i}\end{array}$ & $\begin{array}{c}\text { Frekuens } \\
\mathrm{i}\end{array}$ & $\begin{array}{c}\text { Persentas } \\
\mathrm{e}\end{array}$ \\
\hline SMA & 7 & 23,3 \\
\hline Kuliah & 23 & 76,7 \\
\hline Total & 30 & 100 \\
\hline
\end{tabular}

Karakteristik pendidikan subyek penelitian dari tabel diatas didapatkan hasil bahwa pendidikan respondenyang menjadi subyek penelitian dengan frekuensi terbanyak pada jenjang Universitas dengan jumlah 23 orang $(76,7 \%)$.

\section{Perilaku Caring Perawat}

Tabel 2.

Variabel Perilaku Caring Perawat

\begin{tabular}{cccc}
\hline & & Frekuensi & Persentase \\
\hline Perilaku & Buruk & 15 & 50 \\
Caring & Baik & 15 & 50 \\
Perawat & Total & 30 & 100 \\
\hline
\end{tabular}

Berdasarkan tabel diatas dapat diketahui hasil perilaku caring perawat di Rumah Sakit Khusus Bedah BIMC Siloam Nusa Dua dari 30 responden sebanyak $15 \quad(50 \%)$ responden menyatakan perilaku caring perawat baik dan 15 $(50 \%)$ responden menyatakan perilaku caring perawat buruk

\section{Kepuasan Pasien Asing}

Tabel 3.

Variabel Kepuasan Pasien Asing

\begin{tabular}{llcc}
\hline & & Frekuensi & Persentase \\
\hline Kepuasan & Tidak Puas & 6 & 20.0 \\
\cline { 2 - 4 } Pasien & Puas & 24 & 80.0 \\
\cline { 2 - 4 } Asing & Total & 30 & 100.0 \\
\hline
\end{tabular}

Berdasarkan tabel diatas dapat diketahui hasil kepuasan pasien asing di Rumah Sakit Khusus Bedah BIMC Siloam Nusa Dua dari jumlah responden 30 pasien asing didapatkan hasil bahwa tidak puas yaitu 6 responden (20\%) dan puas 24 responden $(80 \%)$.

\section{Hubungan Perilaku Caring dengan Kepuasan Pasien}

Tabel 4.

Hubungan Perilaku Caring Perawat dengan Kepuasan Pasien Asing

\begin{tabular}{lc}
\hline & Hasil Spearman rho \\
\hline $\mathrm{R}$ & 0,967 \\
\hline$P$ value & 0,000 \\
\hline
\end{tabular}

Berdasarkan uraian tabel diatas memberikan gambaran bahwa sebanyak 30 responden diperoleh nilai signifikan $P_{\text {value }}=0,000$ yang berarti bahwa terdapat hubungan bermakna antara perilaku caring perawat dengan kepuasan pasien asing. Hasil penelitian didapatkan nilai koefisien korelasi sebesar 0,967 yang bermakna tingkat hubungan yang kuat, dengan arah hubungan positif yang berarti jika perilaku caring perawat baik maka pasien asing akan merasa puas, begitu juga sebaliknya jika perilaku caring perawat buruk maka pasien asing akan merasa tidak puas.

\section{PEMBAHASAN}

\section{Perilaku Caring Perawat}

Berdasarkan dari hasil penelitian, didapatkan bahwa dari $15 \quad(50 \%)$ responden mmenyatakan perilaku caring perawat baik. hal ini didukung oleh perawat di Ruang Inap Rumah Sakit BIMC Siloam Nusa Dua yang memiliki sikap, kepribadian dan motivasi yang baik. Selain itu perawat juga memiliki kemampuan dalam berkomunikasi yang baik serta mendapat dukungan dari kepala ruangan dalam mengembangkan kemampuan individu. Perawat dapat meningkatkan kemampuannya dengan belajardari pengalaman ketika bertemu dengan klien, dan dengan mendengarkan keluhan pasien dapat membuat perawat secara langsung terlibat dalam kehidupan klien. Perawat akan dapat merespon secara benar setelah bertemu dengan klien dan keluarganya. Ekspresi wajah pasien dapat membantu perawat menolong pasien mencari cara untuk mendapatkan kedamaian (Patricia A Potter, 2016).

Caring merupakan hubungan transaksi yang dilakukan dan diperlukan antar pasien dan perawat dalam meningkatkan dan melindungi 
pasien sebagai manusia, dengan demikian mempengaruhi kesanggupan pasien untuk sembuh (Watson, 2009). Disisi lain caring merupakan pengetahuan, kemanusiaan, inti dari praktik keperawatan yang bersifat etik dan filosofikal (N. P. Damayanti, Craig, \& Irudayaraj, 2013). Perilaku caring merupakan suatu proses yang memberikan kesempatan pada seseorang, baik pemberi asuhan maupun penerima asuhan keperawatan untuk pertumbuhan pribadi (Marrison, P \& Burnard, 2009).

Selain itu, karena penilitian ini dilakukan diruang rawat inap maka terdapat interaksi yang lebih banyak antara pasien dan perawat sehingga memudahkan terjadinya perilaku caring.Disamping itu, ruang rawat inap memungkinkan responden untuk berpikir dan merasakan perilaku caring perawat untuk menjawab kuesioner yang diberikan dengan kondisi penyakitnya yang tidak kritis. Hal ini juga sejalan dengan pernyataan (Patricia A Potter, 2016) yaitu caring merupakan fenomena universal dengan cara seseorang berfikir, merasa, dan mempunyai hubungan dengan sesama.

Hasil penelitian ini sejalan dengan penelitian yang dilakukan oleh (Ramadhani, 2015) tentang "perilaku caring perawat terhadap kepuasan pasien di ruang rawat inap bedah " menunjukkan bahwa perilaku caring perawat kategori baik (74,6\%), cukup (46,4\%). Bila dilihat dari item pernyataan pada kuesioner perilaku caring perawat dengan jawaban "selalu" yaitu dengan pernyataan perawat Treat me kindly, dan Use my name when they talk to me dengan jumlah $53,3 \%(16 / 30)$. Disamping itu, pernyataan dengan jawaban "sering" yaitu dengan pernyataan perawat respect and pay attention to me and share personal information to me dengan jumlah $56,7 \%$ $(17 / 30)$. Hal ini menunjukkan bahwa perilaku perawat dalam hal mengenai nilai humanistic dan altruistic, serta kemampuan membantu orang lain mengenai kepekaan terhadap diri sendiri dilakukan dengan baik.

\section{Kepuasan Pasien Asing}

Berdasarkan hasil penelitian, dari 30 responden didapatkan bahwa sebanyak 24 (80\%) responden merasa puas dan $6(20 \%)$ responden merasa tidak puas. Hal ini didukung oleh interaksi caring yang baik dari perawat dalam memberikan asuhan keperawatan kepada pasien serta didukung oleh kebersihan ruangan rumah sakit. Menurut pendapat (Pohan, 2006) menyatakan bahwa kepuasan adalah tingkat perasaan pasien yang timbul sebagai akibat dari kinerja layanan kesehatan yang diperolehnya, setelah pasien membandingkan dengan apa yang diharapkannya.

Kepuasan adalah perasaan senang atau kecewa seseorang yang muncul setelah membandingkan antara persepsi atau kesannya terhadap kinerja atau hasil suatu produk dan harapan-harapannya (Kotler, P. \& Keller, 2007). Sementara itu menurut (Tjiptono, 2007) berpendapat bahwa kepuasan pelanggan merupakan respon emosional terhadap pengalaman-pengalaman berkaitan dengan produk atau jasa tertentu yang dibeli, gerai ritel atau bahkan pola perilaku (seperti perilaku berbelanja dan perilaku pembeli), serta pasar secara keseluruhan.

Bila dilihat dari item pernyataan pada kuesioner kepuasan pasien dengan jawaban "puas" yaitu dengan pernyataan The nurses helped me when I was having trouble without being asked dengan jumlah yaitu sebanyak $76,7 \%$ $(23 / 30)$. Disamping itu pernyataan dengan jawaban "puas" yaitu pada pernyataan The nurse explained the recommendation in a way I could understand dengan jumlah yaitu $65,6 \%(20 / 30)$. Hal ini menunjukkan bahwa kepuasan pasien dalam hal mengenai domainresponsiveness (tanggung jawab) serta domain Assurance (Jaminan) cenderung tinggi, sejalan dengan penelitian yang dilakukan oleh (Rafli, F., 2009) "Nurse Caring in Iran and Its Relationship with Patient Satisfaction" menunjukan bahwa yang paling mempengaruhi kepuasan pasien adalah "technical-professional care" yang diberikan oleh perawat, aspek ini berkaitan dengan keterampilan dan pengetahuan professional perawat. Kepuasan pasien akan meningkat jika diberikan informasi dengan tepat dan jelas dalam penyampaiannya, maka dari itu perawat diharapkan mampu memberikan perhatian secara langsung dan selalu menjelaskan informasi dengan tepat dan jelas sesuai keadaan dan pertanyaan yang diajukan pasien.

Dilihat dari karakteristik responden pada penelitian ini $76,67 \%$ (23/30) menyelesaikan pendidikan universitas. Tingkat pendidikan merupakan salah satu faktor mempengaruhi harapan dan persepsi pasien terhadap pelayanan kesehatan. Semakin tinggi tingkat pendidikan seseorang semakin besar pula keinginan dan harapannya, maka tingkat pendidikan yang tinggi akan cenderung menyebabkan kepuasan yang rendah sehingga diperlukan pelayanan yang berkualitas tinggi untuk mendapatkan kepuasan(Notoatmodjo, 2012). 


\section{Hubungan Antara Perilaku Caring Perawat dengan Kepuasan Pasien Asing di Ruang Rawat Inap Rumah Sakit BIMC Siloam Nusa Dua}

Berdasarkan hasil penelitian, didapatkan bahwasebanyak 30 responden diperoleh nilai signifikan $\mathrm{P}_{\text {value }}=0,000$ yang berarti bahwa terdapat hubungan bermakna antara perilaku caring perawat dengan kepuasan pasien asing. Hasil penelitian didapatkan nilai koefisien korelasi sebesar 0,967 yang bermakna tingkat hubungan yang kuat, dengan arah hubungan positif yang berarti jika perilaku caring perawat baik maka pasien asing akan merasa puas, begitu juga sebaliknya jika perilaku caring perawat buruk maka pasien asing akan merasa tidak puas.Hasil penelitian ini didukung oleh perilaku caring perawat di Ruang Rawat Inap Rumah Sakit BIMC Siloam Nusa Dua yang cenderung baik sehingga menyebabkan kepuasan Pasien asing cenderung tinggi pula. Kualitas pelayanan keperawatan mampu memberikan rasa nyaman dan terlindungi pada diri setiap pasien melalui lima dimensi mutu yang sedang menjalani proses penyembuhan dimana sikap ini merupakan kompensasi sebagai pemberi pelayanan dan diharapkan menimbulkan perasaan puas pada diri pasien (Triwibowo, 2013).

Bila dilihat dari item pernyataan pada kedua kuesionervariabel penelitian ini, sebagian besar responden menjawab selalu pada beberapa item pernyataan kuesioner variabel perilaku caring perawat, diantaranya nilai humanistic dan altruistik 53,3\% (16/30), lingkungan yang positif, protektif, perbaikan mental, dan spiritual yaitu sebanyak 53,3\% (16/30), dan kekuatan eksistensial dan fenomenologikal yaitu sebanyak $50,0 \%(15 / 30)$. Searah dengan beberapa item pernyataan kuesioner variabel kepuasan Pasien asingdimana hampir sebagian besar pula responden yang menjawab puas diantaranya, tentangResponsiveness (tanggung jawab) yaitu sebanyak 76,7\% (23/30), tentang Assurance (jaminan) yaitu sebanyak 65,6\% (20/30), dan tentang Tangibles (kenyataan) yaitu sebanyak $63,3 \%$ (19/30). Begitu pula responden yang menjawab tidak pernah pada item pernyataan kuesioner variabel perilaku caring perawat hanya sebagian kecil yaitu kurang dari 10\% responden yang menjawab tidak pernah, searah dengan jawaban tidak puas pada item pernyataan kuesioner kepuasan pasien yaitu 6,7\% responden menjawab tidak puas dan hanya pada pernyataan tentang Emphaty (empati) pasien menjawab tidak puas sebanyak $6,7 \%(4 / 30)$. Hubungan antara pemberi pelayanan kesehatan dengan pasien merupakan faktor yang mempengaruhi proses kepuasan dan kesembuhan pasien tersebut, sehingga seorang perawat harus memiliki perilaku caring dalam pelayanannya terhadap pasien(Watson, 2009). Pendapat Watson juga didukung oleh pendapat dari (Kotler, P. \& Keller, 2007) bahwa kepuasan pasien tergantung pada kinerja dalam memberikan suatu pelayanan, bila kinerja jauh lebih rendah daripada harapan pasien, pasien tidak puas dan bila kinerja pelayanan sesuai dengan harapan maka pasien merasa sangat puas atau dapat diartikan sebagai perbandingan antara harapan yang dimiliki oleh pasien dengan kenyataan yang diterima oleh pasien pada saat menerima pelayanan.

\section{KESIMPULAN}

Kesimpulan dalam penelitian ini adalah terdapat hubungan yang signifikan antara perilaku caring perawat dengan kepuasan warga negara asing dengan hubungan yang kuat dan arah korelasi positif.

Peeliti berharap hasil penelitian ini dapat dijadikan rujukan dalam peningkatan pelayanan keperawatan dalam wujud caring dalam upaya peningkatan kepuasan pasien.

\section{DAFTAR PUSTAKA}

BPS Kabupaten Badung. (2016). BPS Kabupaten Badung. Retrieved from https://badungkab.bps.go.id/subject/153/ge ografi.html\#subjekViewTab3

Damayanti, D. (2013). Buku Pintar Perawat Professional Teori dan Praktik Asuhan Keperawatan.

Damayanti, N. P., Craig, A. P., \& Irudayaraj, J. (2013). A hybrid FLIM-elastic net platform for label free profiling of breast cancer. Analyst. https://doi.org/10.1039/c3an01097j

Geri-ann, G. (2015). Caring for Patient from Different Culture. In Caring for Patient from Different Culture. (Vol. 5th). University of Pennsylvania Press. 
Hajinezhad. (2009). Nurse Caring in Iran and Its Relationship with Patient Satisfaction. Australian Nursing Federation.

Haryono, R. (2013). Etika Keperawatan dengan Pendekatan Praktik. Etika Keperawatan Dengan Pendekatan Praktik. Yogyakarta: Gosyen Publishing.

Hidayat, A. A. (2007). Keperawatan \& Teknik Penulisan Ilmiah. In Keperawatan \& Teknik Penulisan Ilmiah. Jakarta: Salemba Medika.

Ismail, E. al. (2012). Correlation Between Nurses Caring Behaviors and Patient Satisfaction. Nurse midwifery stud. Correlation Between Nurses Caring Behaviors and Patient Satisfaction. Nurse Midwifery Stud. Retrieved from www.nmsjournal.com

J Kristianto. (2015). Mutu Rumah Sakit Dapat Mencegah Malpraktik Terjadi di Rumah Sakit. Mutu Rumah Sakit Dapat Mencegah Malpraktik Terjadi Di Rumah Sakit. Retrieved from https://scholar.google.co.id/scholar?oi=bibs $\&$ cluster $=9711751511972075171 \& \mathrm{btnI}=1$ $\&$ hl $=$ en

Kalsium, U. (2016). Hubungan Perilaku Caring Perawat dengan Kepuasan Pasien di Ruang Perawatan Teratai Rumah Sakit Umum Pusat Fatmawati tahun 2016. Hubungan Perilaku Caring Perawat Dengan Kepuasan Pasien Di Ruang Perawatan Teratai Rumah Sakit Umum Pusat Fatmawati Tahun 2016. Retrieved from http://repository.uinjkt.ac.id/dspace/bitstrea m/123456789/32964/1/UMI KALSUMFKIK

Kaltara. (2009). Response to the Power of Human Caring: Early Recognition of Patient Problem Scholarly Ingury for Nursing Practice: An International Journal. Response to the Power of Human Caring: Early Recognition of Patient Problem Scholarly Ingury for Nursing Practice: An International Journal, 9, 4.

Kotler, P. \& Keller, K. . (2007). Manajemen Pemasaran. Edisi Kedua Belas Jilid 1. Edisi Bahasa Inggris. Person Education, Inc. Upper Saddler River, New Jersey, 07458,
Edisi Bahasa Indonesia, Pada PT.INDEKS. Manajemen Pemasaran. Edisi Kedua Belas Jilid 1. Edisi Bahasa Inggris. Person Education, Inc. Upper Saddler River, New Jersey, 07458, Edisi Bahasa Indonesia, Pada PT.INDEKS.

Kurnia, Y. D. (2017). Gambaran Perilaku Caring Perawat Di Ruang Paviliun Dan Rawat Inap Kelas III Rumah Sakit Daerah dr. Soebandi Universitas Jember. Skripsi. Retrieved from http://repository.unej.ac.id/handle/1234567 $89 / 82813$

Mailani, F. (2017). hubungan perilaku caring perawat dengan tingkat kepuasan pasien BPJS di ruang rawat inap RSUD.dr. Rasidin Padang. Hubungan Perilaku Caring Perawat Dengan Tingkat Kepuasan Pasien BPJS Di Ruang Rawat Inap RSUD.Dr. Rasidin Padang.

Mamik. (2010). Organisasi dan Manajemen Pelayanan Kesehatan dan Kebidanan. Organisasi Dan Manajemen Pelayanan Kesehatan Dan Kebidanan., 1(Surabaya: Prins Media Publishing.).

Marrison, P \& Burnard, P. (2009). Caring And Communicating: Hubungan Interpersonal dalam Keperawatan. Jakarta : EGC. Caring And Communicating: Hubungan Interpersonal Dalam Keperawatan. Jakarta : EGC.

Nanda, S. \&. (2011). Konsep Caring. Konsep Caring. Retrieved from http://www.pedoman.news.com

Nasution, M. N. (2010). Manajemen Mutu Terpadu (Total Quality Manajement). Jakarta: Ghalia. Manajemen Mutu Terpadu (Total Quality Manajement). Jakarta: Ghalia.

Nooria, W. (2008). Pengaruh persepsi kualitas jasa pelayanan terhadap kepuasan dan loyalitas pelanggan di RSU Saras Husada Purworejo. Fakultas Psikologi. Universitas Muhamadyah Surakarta. Pengaruh Persepsi Kualitas Jasa Pelayanan Terhadap Kepuasan Dan Loyalitas Pelanggan Di RSU Saras Husada Purworejo. Fakultas Psikologi. Universitas Muhamadyah Surakarta. 
Notoatmodjo, S. (2012). Metodelogi Penelitian Kesehatan. Jakarta: Rineka Cipta.

Nurhayati. (2013). Hubungan Perilaku Caring Perawat Dengan Tingkat Kecemasan Pasien Rawat Inap Di Rumah Sakit PKU Muhammadiyah Surakarta. Hubungan Perilaku Caring Perawat Dengan Tingkat Kecemasan Pasien Rawat Inap Di Rumah Sakit PKU Muhammadiyah Surakarta. Retrieved from http://eprints.ums.ac.id/27204/16/02_NAS KAH_PUBLIKASI.pdf

Nursalam. (2011). Manajemen Keperawatan. Manajemen Keperawatan, 3(salemba medika).

Patricia A Potter. (2016). Fundamental Of Nursing. Retrieved from https://books.google.co.id/books?id=eCKK CwAAQBAJ

Pohan. (2006a). Jaminan Mutu Layanan kesehatan: dasar-dasar pengertian dan penerapan. Jaminan Mutu Layanan Kesehatan: Dasar-Dasar Pengertian Dan Penerapan, Jakarta: $B$.

Pohan, I. (2006b). Jaminan Mutu Layanan Kesehatan. Jaminan Mutu Layanan Kesehatan, (Jakarta: EGC).

Putra. (2014). Potensi Pengembangan Medical Tourism di Rumah Sakit Balimed Denpasar. Potensi Pengembangan Medical Tourism Di Rumah Sakit Balimed Denpasar. Retrieved from

http://etd.repository.ugm.ac.id/index.php?m od

Rafli, F., et al. (2009). Nurse Caring in Iran and Its Relationship with Patient Satisfaction. Australian Journal of Advanced Nursing. Nurse Caring in Iran and Its Relationship with Patient Satisfaction. Australian Journal of Advanced Nursing, 26, 2. Retrieved from https://www.researchgate.net/publication/2 87857029_Nurse_caring_in_Iran_and_its_r elationship_with_patient_satisfaction

Ramadhani. (2015). perilaku caring perawat terhadap kepuasan pasien di ruang rawat inap bedah. Perilaku Caring Perawat Terhadap Kepuasan Pasien Di Ruang Rawat Inap Bedah.

RI, D. (2008). Standar Pelayanan Rumah Sakit. Standar Pelayanan Rumah Sakit.

Santoso, S. (2010). Statistik Non Parametrik Konsep dan Aplikasi dengan SPSS. Jakarta: Elex Media Komputindo.

Saryono. (2010). Metodelogi Peneitian Kesehatan Penuntun Praktis Bagi Pemula. Metodelogi Peneitian Kesehatan Penuntun Praktis Bagi Pemula, (Yogyakarta :Mitra Cendikia.).

Sastroasmoro. (2011). Dasar-dasar Metodologi Penelitian Klinis. Dasar-Dasar Metodologi Penelitian Klinis.

Setiadi. (2007). Konsep \& Proses Keperawatan Keluarga. Konsep \& Proses Keperawatan Keluarga.

Shelton. (2010). spirituality, Mental Health and The new Physics. Spirituality, Mental Health and The New Physics.

Siagaan, S. (2010). Manajemen Sumber Daya Manusia. Manajemen Sumber Daya Manusia, (Jakarta: Bumi Aksara).

Siswanto, D. (2013). Metodelogi Penelitian Kesehatan dan Kedokteran. Pustaka Ilmu.

Sugiyono. (2013). statistik untuk Penelitian Kuantitatif dan Kualitatif. Bandung: Alfabet.

Supardi. (2009). analisis kualitas pelayanan terhadap kepuasan pelanggan. Analisis Kualitas Pelayanan Terhadap Kepuasan Pelanggan.

Suryani. (2015). Komunikasi Terapeutik teori dan praktik (Ed 2). ECG.

Suwardana, D. M. (2014). Hubungan pelaksanaan pelayanan perawat dengan kepuasan pasien rawat inap di rsud kabupaten bombana. Hubungan Pelaksanaan Pelayanan Perawat Dengan Kepuasan Pasien Rawat Inap Di Rsud Kabupaten Bombana. Retrieved from 
www.academia.edu/852290.com

Swarjana, I. K. (2015). Metodologi Penelitian Keasehatan Edisi Revisi. Yogyakarta: Cv.Andi OFFSET.

Tjiptono, F. (2007). Hubungan Mutu Pelayanan Keperawatan dengan Kepuasan Pasien Rawat Inap Dewasa Kelas II dan III RS PKU Muhammadiyah. [Tesis]. STIKES Aisyiyah Yogyakarta. Hubungan Mutu Pelayanan Keperawatan Dengan Kepuasan Pasien Rawat Inap Dewasa Kelas II Dan III RS PKU Muhammadiyah. [Tesis]. STIKES Aisyiyah Yogyakarta.

Triwibowo, C. (2013). Manajemen Pelayanan dan Keperawatan di Rumah Sakit. Manajemen Pelayanan Dan Keperawatan Di Rumah Sakit.

Watson, J. (2009). Theory of Human Caring. Theory of Human Caring., (. Boston: Little Brown). Retrieved from http://www2.uchsc.edu/son /caring

Zees, R. F. (2011). Analisis faktor budaya organisasi yang berhubungan dengan perilaku caring perawat pelaksana di Ruang Rawat Inap RSUD Prof. Dr. H. Aloesi Saboe Kota Gorontalo. [Tesis]. Fakultas Ilmu Keperawatan: Universitas Indonesia. Analisis Faktor Budaya Organisasi Yang Berhubungan Dengan Perilaku Caring Perawat Pelaksana Di Ruang Rawat Inap RSUD Prof. Dr. H. Aloesi Saboe Kota Gorontalo. [Tesis]. Fakultas Ilmu Keperawatan: Universitas Indonesia.

Zukhrina, H. (2015). Kesiapan Tenaga Kesehatan Indonesia untuk Menghadapi Tenaga Kesehatan Asing. Kesiapan Tenaga Kesehatan Indonesia Untuk Menghadapi Tenaga Kesehatan Asing. 